\title{
EXTENSIVE AND INTENSIVE ECONOMY GROWTH IN THE CONTEXT OF EU CYCLICAL DEVELOPMENT
}

\author{
[Extenzivní a intenzivní hospodářský růst v kontextu cyklického vývoje EU] \\ Tomáš Volek ${ }^{1}$, Martina Novotná ${ }^{2}$ \\ ${ }^{1}$ Jihočeská univerzita, Ekonomická fakulta, Studentská 13, 37005 České Budějovice \\ Email:volek@ef.jcu.cz \\ ${ }^{2}$ Jihočeská univerzita, Ekonomická fakulta, Studentská 13, 37005 České Budějovice \\ Email: novotna@ef.jcu.cz
}

\begin{abstract}
The main aim of this paper is to consider if it is the extensive or intensive growth sources which prevail in particular member states of the EU during the total productivity of production factors in different phases of the business cycle of the EU. The paper focuses on the period of 1996-2011, i.e. 16 years. The conducted analysis revealed that there is a relation between the extensive and intensive growth sources on the economic cycle. It was found that in economic growth periods, the importance of the intensive growth increases, while in the periods when the gross added value increases, the dominant role is played by the extensive growth. From the point of view of particular member states of the EU, the analysis identified that there are significant differences between the old member states of the EU and the new member states. In the new member states, the extensive growth factor has a significantly higher influence, which is related to the increase of their production capacity.
\end{abstract}

Keywords: business cycle, economic growth, EU, productivity, source of growth.

JEL classification: D24, E01, E23

Doručeno redakci: 5.3.2013; Recenzováno: 20.5.2013; 21.5.2013; Schváleno k publikování: 16.6.2014

\section{Úvod}

Ekonomický růst státu je nutné chápat komplexně, kdy na jedné straně stojí zdroje ekonomické růstu a na druhé faktory, které ho ovlivňují a to jak pozitivně, tak i negativně. Význam zdrojů růstu v rámci jednotlivých států není identický. V jednotlivých členských státech působí na ekonomický růst řada faktorů jako ekonomická úroveň státu nebo vzájemná větši či menší provázanost ekonomik některých států, $\mathrm{z}$ nichž také mohou pramenit odlišnosti ve zdrojích růstu. Významem a hledáním zdrojů ekonomického růstu státu se již zabýval Solow (1956), Barro (2004). Vliv hospodářského cyklu na ekonomický růst popisuje Kydland a Prescott (1982). Uvedená stat' se zabývá zdroji ekonomického růstu na jedné straně a na druhé jejich významem v rámci hospodářského cyklu. Uvedenou oblastí se zabýval Hájek a Mihola (2009) na př́kladu České republiky, avšak z pohledu všech státu Evropské unie zatím uvedená analýza chybí. Za hlavní přidanou hodnotu článku lze považovat určení hlavních zdrojů růstu $\mathrm{v}$ jednotlivých fázích hospodařského cyklu Evropské unie v jednotlivých státech EU. Je tedy otázkou, jaký vliv má cyklický vývoj ekonomiky EU na zdroje ekonomického růstu $\mathrm{v}$ jednotlivých ekonomikách členských států. V tomto př́spěvku autoři opomíjejí vliv provázanosti ekonomik některých členských států, nebot' tyto státy jsou propojené v rámci ekonomiky Evropské unie. Význam ekonomické úrovně států je zohledněn v poslední části př́spěvku.

Základním východiskem při měření ekonomického růstu a produktivity je produkční funkce, kterou můžeme zapsat jako $\mathrm{Y}=\mathrm{F}(\mathrm{T}, \mathrm{K}, \mathrm{L})$, kde $\mathrm{T}$ je úroveň technologií a znalostí, $\mathrm{K}$ je objem fyzického kapitálu, L je množství práce (Barro, Sala-i-Martin 2004, str. 24). 
Produkční funkce jasně ř́ká, že hrubý domácí produkt (GDP) tj. Y, může růst jen tehdy, jestliže rostou vstupy včetně úrovně technologií.

Zdroje ekonomického růstu můžeme rozdělit na extenzivní, následně mluvíme o takzvaném extenzivním růstu nebo mohou být intenzivní, pak hovoříme o takzvaném intenzivním růstu.

O převážně extenzívním hospodářském růstu se hovoří, pokud jsou pro něj rozhodující zvyšující se objemy výrobních faktorů (Soukup 2007). Extenzivní růst vychází z růstových strategií založených na rozšíření vstupů. Ty mohou být představovány růstem akumulace kapitálu a růstem pracovní síly vedoucím ke zvýšení tempa růstu celkového výstupu (Irmen 2005). Přesto tyto růstové efekty nemusí vést ke stálému růstu výstupu na obyvatele, nebot' jsou ovlivňovány celou řadou dalších faktorů.

V př́ípadě intenzivního růstu pak převažuje vliv zlepšující se kvalifikace pracovních sil a zvyšující se technologické úrovně kapitálových statků (Soukup 2007). Tento zdroj růstu často nazýváme kvalitativním růstem, který je způsobem zvyšováním technologií či technologickým pokrokem. Intenzivní růst respektive zavádění nových technologií a koncentrace může mít na jedné straně pozitivní vliv na produktivitu práce na druhou i negativní vliv na produktivitu kapitálu. (Banda, Verdugo 2011). Extenzivní a intenzivní růst je výrazně ovlivněn makroekonomickým a makro-institucionálním prostředím, ve kterém se nachází podniky v ekonomice (Ahlin 2011).

Pokud mluvíme o extenzivním a intenzivním růstu, jde reálně o výsledek kvalitativních a kvantitativních změn produktivit výrobních faktorů (Hájek, Mihola 2009) a to jak jednotlivě tak u výrobních faktorů jako celku. Produktivitu můžeme obecně definovat jako poměr výstupu a vstupu (Coelli et al. 2005). Nejjednodušší a nejvíce časté je měření produktivity práce. Produktivitu práce můžeme definovat jako hrubou přidanou hodnotu nebo hrubý výstup na pracovníka či odpracovanou hodinu (O’Mahony at. al. 2008). Základní rozdíl $\mathrm{v}$ hodnocení produktivity práce spočívá $\mathrm{v}$ tom, jakou roli hraje práce. V některých př́padech je práce primárním nástrojem pro dosažení konečného produktu (Baumol 1967), v jiných př́padech může být hlavním zdrojem např́iklad technologických pokrok. Dále můžeme měřit produktivitu kapitálu vycházející z fyzické zásoby kapitálu (Yasser, Joutz 2005). Produktivita kapitálu tedy ukazuje, jak je kapitál využiván při tvorbě přidané hodnoty ekonomiky. Zvyšování produktivity práce a kapitálu považuje za extenzívní faktor ekonomického růstu. Souhrnný ukazatel produktivity, kterým se již zabývá Solow (1957), je produktivita výrobních faktorů (TFP - Total Factor Productivity). TFP měří výstup vázaný na každou jednotku práce a kapitálu (Yasser, Joutz 2005), či dalších faktorů produkce. TFP je základem pro posouzení agregovaného tempa růstu výstupu a ocenění prínosu technologického pokroku. Produktivita výrobních faktorů tedy představuje koncept, který měři efekt technologických změn v produktivitě a je hnacím kolem ekonomického růstu (Praag, Versloot 2008).

Mezi další významný faktor, který má nemalý vliv na ekonomický růst a produktivitu je hospodářský cyklus. Základní teorií je dnes teorie reálného hospodářského cyklu (RBC- real business cycle). Hlavními autory jsou Kydland, Prescott (1982). Tento koncept je zaměřen na vysvětlení výkyvů vekonomice. Podstatou teorie reálných hospodářských cyklů je vysvětlení př́icin hospodářského cyklu, spočívajících v reálných šocích, které ovlivňují ekonomiku a také i produktivitu. Na základě uvedených teorií v této souvislosti vyvstává otázka, jakou roli $\mathrm{v}$ různých fázích hospodářského cyklu má extenzivní či intenzivní zdroj růstu ekonomiky. Cílem uvedené stati je tedy posoudit, zda převažují v jednotlivých fázích 
hospodářského cyklu EU extenzivní či intenzivní zdroje růstu v jednotlivých státech Evropské unie.

\section{Metodika}

Pro analytickou část bylo zvoleno období 1996-2011 tj. interval 16 let s vědomím, že některé státy nebyly po celé období členskými státy Evropské unie. Hodnoty sledovaných ukazatelů byly zjišt'ovány jako reálné prostřednictvím EUROSTATU a to $\mathrm{v}$ ocenění PPS tj. $\mathrm{v}$ paritě kupní síly měny, které se doporučuje pro mezinárodní srovnávání. Toto ocenění vychází pouze $\mathrm{z}$ cenových relací zboží $\mathrm{v}$ různých státech a stranou se ponechává vliv nabídky a poptávky po měnách států (Jílek, 2005, str. 219). Sledované období bylo rozděleno do intervalů určujících fáze reálného hospodářského cyklu dle vývoje hrubé přidané hodnoty $(\mathrm{HPH})$ v EU (27 zemí).

Zvolenými ukazateli byly: produktivita práce (tj. hrubá přidaná hodnota/celková zaměstnanost - domácí koncept), produktivita kapitálu (hrubá přidaná hodnota/tvorba hmotného fixního kapitálu), vybavenost práce kapitálem (tvorba hmotného fixního kapitálu/ celková zaměstnanost - domácí koncept), reálné jednotkové pracovní náklady (náhrady zaměstnancům/ hrubá přidaná hodnota), souhrnná produktivita výrobních faktorů (TFP = $\left.\boldsymbol{A}_{1} / \boldsymbol{A}_{0}\right)$

$$
\frac{\mathrm{A}_{1}}{\mathrm{~A}_{0}}=\frac{\mathrm{Y}_{1}}{\mathrm{Y}_{0}} \cdot\left(\frac{\mathrm{K}_{1}}{\mathrm{~K}_{0}}\right)^{-\alpha_{\mathrm{Kt}}} \cdot\left(\frac{\mathrm{L}_{1}}{\mathrm{~L}_{0}}\right)^{-\alpha_{\mathrm{Lt}}}
$$

kde

$\boldsymbol{Y}_{1} / \boldsymbol{Y}_{0}$ je index reálného produktu (hrubé přidané hodnoty),

$\boldsymbol{K}_{1} / \boldsymbol{K}_{0}$ je index reálné hrubé zásoby dlouhodobého majetku (index tvorby hmotného fixního kapitálu),

$\boldsymbol{L}_{1} / \boldsymbol{L}_{0}$ je index počtu odpracovaných hodin, resp. průměrného počtu pracovníků,

$\alpha_{\mathrm{Lt}}$ je aritmetický průměr z podílu náhrad zaměstnancům na hrubé přidané hodnotě $\mathrm{v}$ základním a běžném období,

$\alpha_{\mathrm{Kt}}$ je aritmetický průměr z podílů hrubého provozního přebytku na hrubé přidané hodnotě v základním a běžném období, takže platí, že $\alpha_{\mathrm{Lt}}+\alpha_{\mathrm{Kt}}=1$.

Při výpočtu byl využit Törnquistův vzorec diskrétní aproximace Divisiova integrálního indexu, a to:

$\ln A_{t}-\ln A_{t-1}=\left(\ln Y_{t}-\ln Y_{t-1}\right)-\alpha_{K t}\left(\ln K_{t}-\ln K_{t-1}\right)-\alpha_{L t}\left(\ln L_{t}-\ln L_{t-1}\right)$.

Z toho vyplývá:

$\left(\ln Y_{t}-\ln Y_{t-1}\right)=\left[\left(\ln A_{t}-\ln A_{t-1}\right)\right]+\left[\alpha_{K t}\left(\ln K_{t}-\ln K_{t-1}\right)+\alpha_{L t}\left(\ln L_{t}-\ln L_{t-1}\right)\right]$. 
První hranatá závorka vzorce 3 představuje intenzitní faktor růstu reálného produktu (i), druhá hranatá závorka je extenzivním faktorem růstu (e).

Relativně je možné oba faktory vyjádřit takto:

$$
\begin{aligned}
& i=\frac{\ln A_{t}-\ln A_{t-1}}{\left|\left(\ln A_{t}-\ln A_{t-1}\right)\right|+\left|\left[\alpha_{K t}\left(\ln K_{t}-\ln K_{t-1}\right)+\alpha_{L t}\left(\ln L_{t}-\ln L_{t-1}\right)\right]\right|}, \\
& e=\frac{\alpha_{K t}\left(\ln K_{t}-\ln K_{t-1}\right)+\alpha_{L t}\left(\ln L_{t}-\ln L_{t-1}\right)}{\left|\left(\ln A_{t}-\ln A_{t-1}\right)\right|+\left|\left[\alpha_{K t}\left(\ln K_{t}-\ln K_{t-1}\right)+\alpha_{L t}\left(\ln L_{t}-\ln L_{t-1}\right)\right]\right|},
\end{aligned}
$$

přičemž mezi oběma parametry platí následující vztah:

$|i|+|e|=1$.

Vztah zajišt'uje, aby oba uvažované faktory pokrývaly právě $100 \%$ při zohlednění možnosti jejich protichůdného až plně kompenzačního působení.

Výpočet průměrných ročních indexů tj. průměrných temp růstu sledovaných produktivit za dílčí časové intervaly byl proveden pomocí geometrického průměru:

$$
\bar{k}=\sqrt[n]{k_{1} \cdot k_{2} \ldots \cdot k_{n}}=\sqrt[n]{\frac{u_{1}}{u_{0}} \cdot \frac{u_{2}}{u_{1}} \ldots \cdot \frac{u_{n}}{u_{n-1}}}=\sqrt[n]{\frac{u_{n}}{u_{0}}},
$$

kde $\bar{k}$ je průměrné tempo růst resp. průměrný koeficient růstu

$$
\begin{aligned}
& k_{1} \ldots k_{n} \text { jsou řetězové indexy ukazatelů } \\
& u_{0} \ldots u_{n} \text { jsou hodnoty jednotlivých ukazatelů. }
\end{aligned}
$$

Tomuto průměru se pro zjišt'ování průměrných ročních temp růstu dává přednost pro jeho, z definice vyplývající, vlastnost. Totiž geometrický průměr nahrazuje individuální hodnoty znaku tak, že se nemění jejich součin (Cyhelský, 1981, str. 70).

\section{Výsledky}

První část, která je nezbytná pro danou analýzu, je konstrukce intervalů určujících fáze reálného hospodářského cyklu. Konstrukce vychází z meziročního vývoje (temp růstu) hrubé přidané hodnoty v EU v paritě kupní síly. Z vývoje hrubé přidané hodnoty za EU (27 zemí) je možné identifikovat intervaly, pomocí kterých můžeme shrnout období 16 let (1996 2011) do následujících pěti intervalů:

- Období 1996 - 2000 je charakteristické stabilními až mírně rostoucími meziročními prírůstky $\mathrm{HPH}$,

- Období 2000 - 2003 se vyznačuje snižujícími se tempy růstu HPH,

- Období 2003 - 2007 naznačuje opětovně zvyšující přírůstky HPH,

- Období 2007 - 2009 je možné označit za období strmě klesajících přírůstků HPH, kdy v roce 2009 se prrírůstek HPH dostává do záporných hodnot tj. tempo růstu v tomto roce je menší než 1 ,

- Období 2009-2011 - znamená pomalou obnovu zvyšujících se temp růstu.

Vymezení délky intervalů není časově stejně dlouhé. Důvodem je rozdílná délka fází reálného hospodářského cyklu EU (27 zemí). 
Mezi jednotlivými obdobími lze zaznamenat odlišný vývoj průměrného ročního tempa ukazatelů produktivity a technického vybavení práce (tab. 1). Tabulka 1 uvádí průměrná roční tempa růstu sledovaných ukazatelů vybraných ukazatelů efektivnosti výrobních faktorů za EU-27 dle identifikovaných intervalů.

Tabulka 1: Tempo růstu ukazatelů za průměr EU 27zemí

\begin{tabular}{|l|c|c|c|c|c|}
\hline & $1996-2000$ & $2000-2003$ & $2003-2007$ & $2007-2009$ & $2009-2011$ \\
\hline produktivita práce & 1,0418 & 1,0273 & 1,0379 & 0,9819 & 1,0428 \\
\hline produktivita kapitálu & 0,9882 & 1,0224 & 0,9762 & 1,0673 & 1,0236 \\
\hline TFP & 1,0178 & 1,0251 & 1,0095 & 1,0194 & 1,0342 \\
\hline technické vybavení práce & 1,0543 & 1,0048 & 1,0632 & 0,9200 & 1,0188 \\
\hline
\end{tabular}

Zdroj: vlastní zpracování, Eurostat

Období stabilního růstu HPH v EU-27 zemí (1996-2000) se vyznačuje vysokými průměrnými ročními př́růstky produktivity práce, zatímco produktivita kapitálu důsledkem zvyšujícího technického vybavení práce klesá. V tomto období se zvyšují investice do hmotného dlouhodobého majetku (vyjádřené v národním účetnictví ukazatelem hrubá tvorba fixního kapitálu), které se projevují snižující se produktivitou kapitálu. Tato situace nastává v př́ípadě, že investovaný kapitál nemá takovou produkční schopnost, aby současně stejnými resp. větším tempem rostl i výstup ekonomiky. Investice se mohou projevit až s časovým posunem. Obdobné průměrné roční tempo růstu produktivity práce můžeme zaznamenat v intervalu 2009-2011, kde je zřejmý opětovný růst hrubé přidané hodnoty na pracovníka. V tomto období i přes mírný růst technického vybavení práce, stále mírně roste produktivita kapitálu, stejně tak i souhrnná produktivita. Dochází také $\mathrm{k}$ průměrnému ročnímu poklesu reálných jednotkových pracovních nákladů, což je další pozitivní jev z pohledu zvyšování konkurenceschopnosti výrobců.

V intervalu zvyšujících se prŕrůstků HPH (2003-2007) se prakticky nejvíce za celé sledované období 16 let zvyšuje technické vybavení práce (průměrný roční nárůst $6,32 \%$ ). Tato skutečnost se odráží v produktivitě kapitálu. TFP v tomto období stále roste důsledkem tempa růstu produktivity práce i přes pokles produktivity kapitálu.

Ve dvou intervalech snižujících se temp růstu hrubé přidané hodnoty na pracovníka (20002003 a 2007-2009) se vývoj sledovaných ukazatelů liší. Poslední zmíněné období je převážně ovlivněno krizovým rokem 2009. V období 2000-2003 můžeme zaznamenat cca stejná průměrná roční tempa růstu všech ukazatelů produktivit (cca 2,5\%). Zatímco v období 20072009 je charakteristické průměrným ročním poklesem technického vybavení práce (pokles $8 \%$ ), produktivity práce (pokles cca 1,8\%). Produktivita kapitálu roste díky snižujícímu se tempu růstu hmotného dlouhodobého majetku.

Z grafu 1 je patrný vzájemný vztah všech zjišt'ovaných ukazatelů produktivit. Můžeme zde zaznamenat antagonistický vztah, kdy s růstem produktivity práce klesá produktivita kapitálu. Naopak dynamika celkové produktivity výrobních faktorů se významně nevychyluje. 
Graf 1: Vývoj ukazatelů produktivit v EU-27 zemí v jednotlivých intervalech

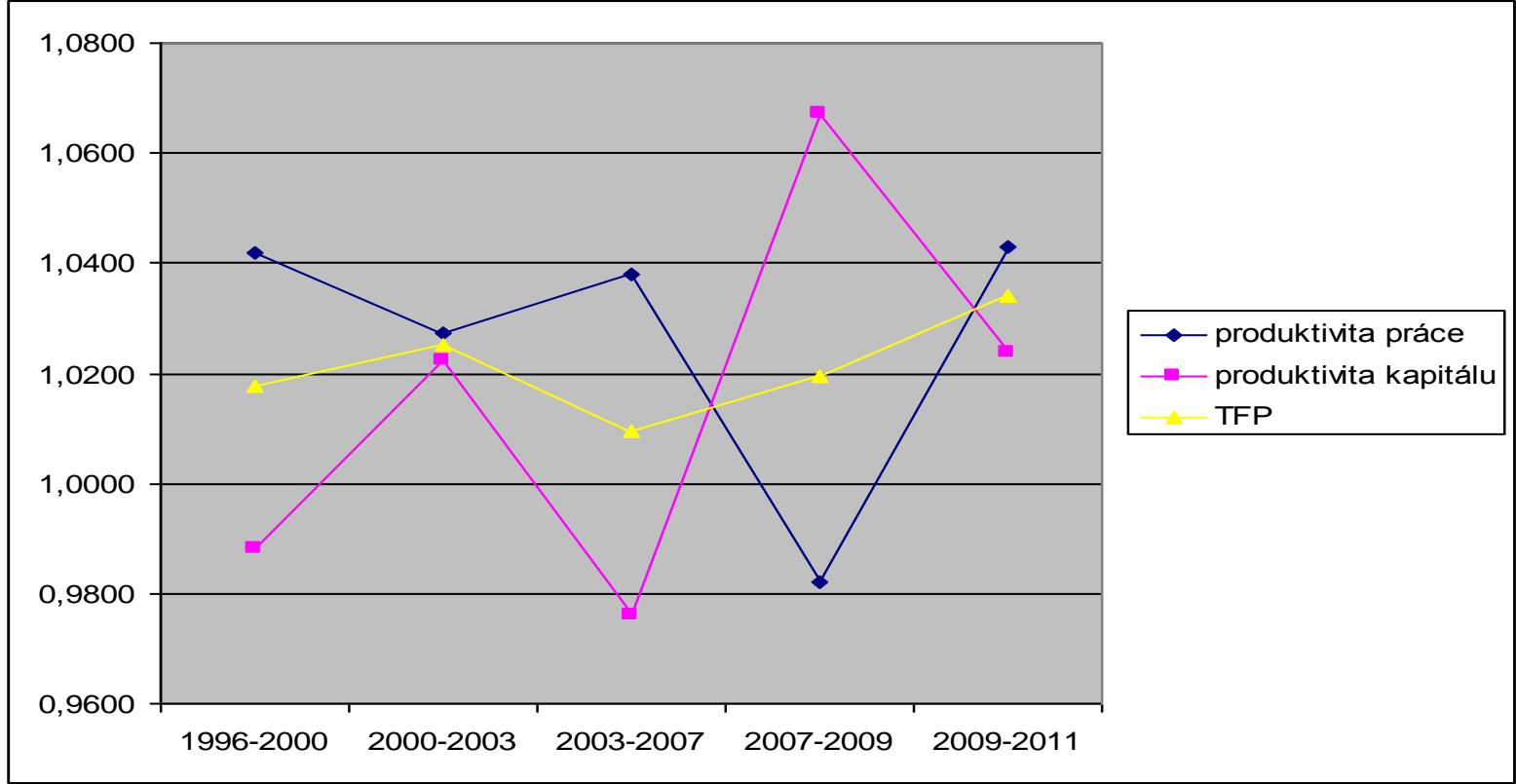

Zdroj: vlastní zpracování, Eurostat

Zdroje ekonomického růstu a jejich význam na celkové produktivitě výrobních faktorů $\mathrm{v}$ rámci EU $27 \mathrm{v}$ letech zobrazuje graf $2 . \mathrm{Z}$ tohoto grafu je zřejmý vliv hospodářského cyklu projevující se snižováním či zvyšováním významu extenzivního a intenzivního zdroje růstu. Můžeme zde zaznamenat, že v obdobích ekonomického poklesu (viz konstruované intervaly výše) roste vliv intenzivního růstu a vobdobích velkého ekonomického růstu vliv extenzivního růstu. Hlavní růstový potenciál extenzivního růstu byl primárně zaznamenán ve státech střední a východní Evropy (viz níže).

Graf 2: Vývoj podílu intenzivní a extenzivní růstu v EU-27

\section{Vývoj faktorů TFP v EU-27zemí v letech 1996-2010}

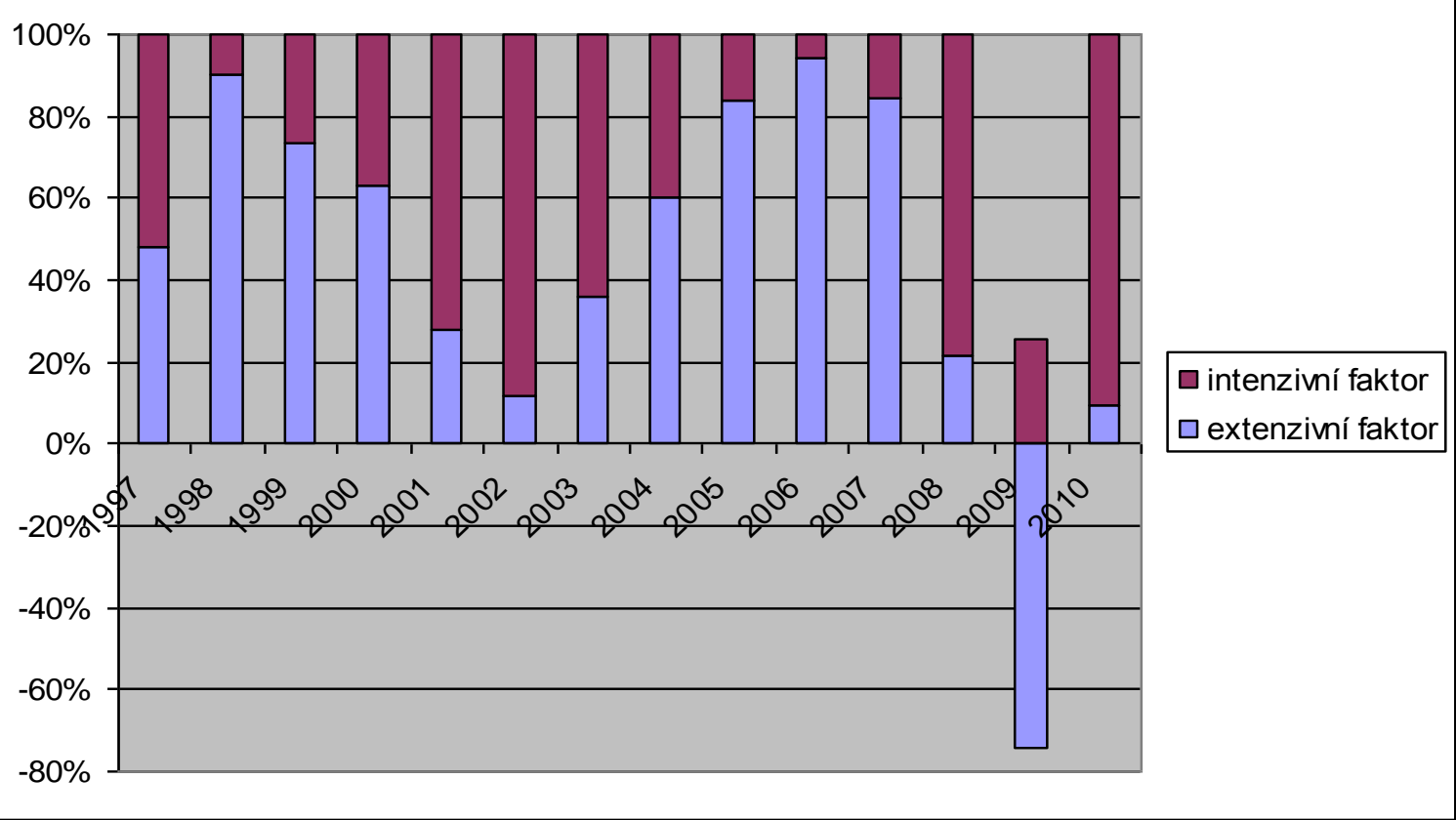

Zdroj: vlastní zpracování, Eurostat 
Tvrzení o závislosti vývoje HPH a vývoje extenzitního faktoru bylo ještě prověřeno prostřednictvím korelační analýzy, přesněji byl zjištěn korelační koeficient, který vyjadřuje těsnost lineární závislosti. Tento koeficient naznačuje poměrně těsnou lineární závislost $(\mathrm{r}=$ 0,83), tj. zvyšuje-li se HPH, zvyšuje se také extenzitní faktor růstu. Uvedenou závislost také ilustruje bodový graf (graf 3 ).

Graf 3: Bodový graf extenzivní faktor vs. index HPH

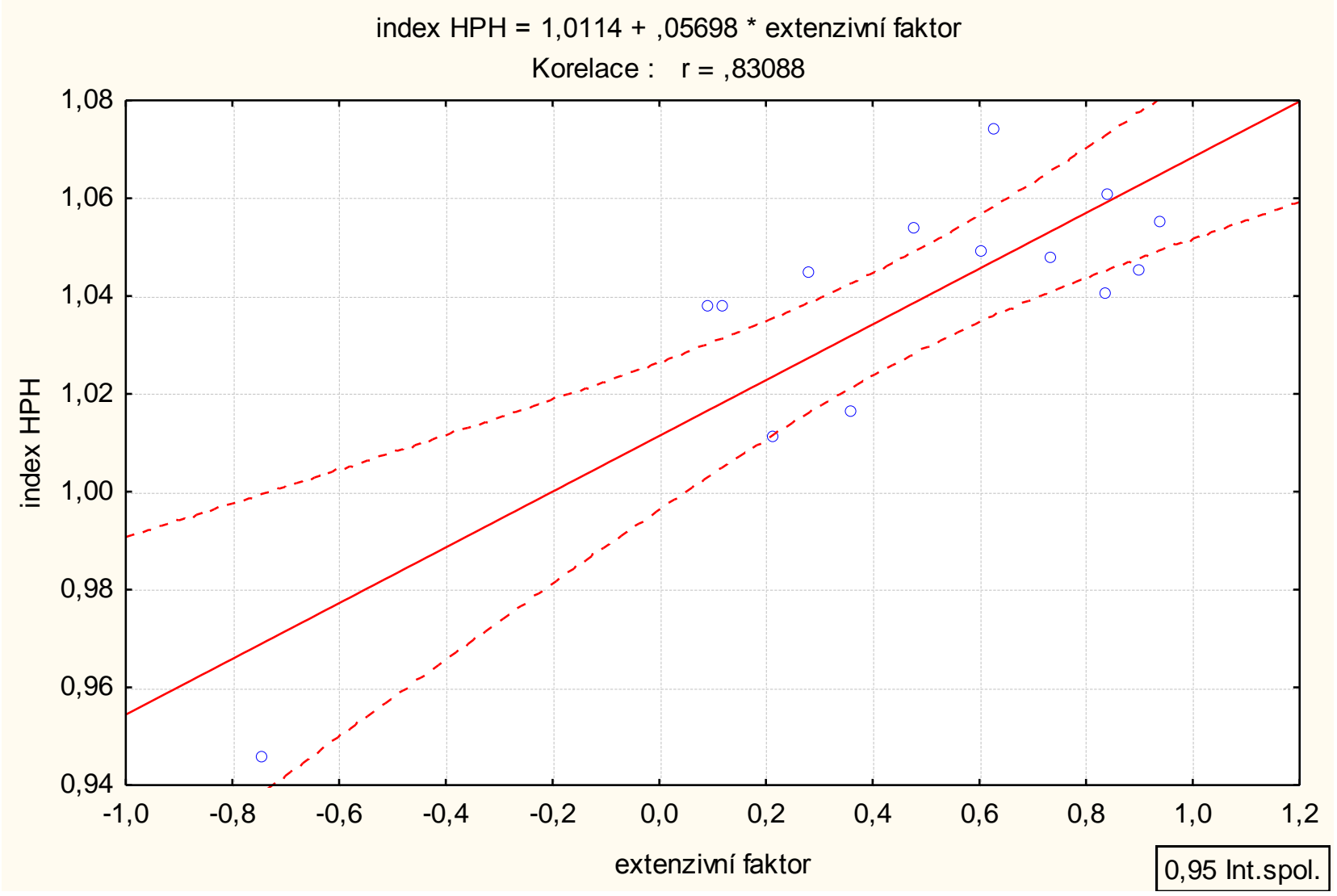

Zdroj: vlastní zpracování

\subsection{Význam intenzivního a extenzivního faktoru růstu $v$ jednotlivých zemích $E U$}

Další část př́spěvku se zabývá zdroji růstu TFP v jednotlivých státech Evropské unie v obdobích zvyšujících se přirůstků HPH, stabilních př́růstku HPH a klesajících přírůstků HPH. Tabulky 2-5 rozdělují státy EU do pěti intervalů, a to jak z pohledu extenzivního, tak intenzivního faktoru růstu. Intervaly jsou konstruovány podle procentního zastoupení každého z faktorů (resp. soubor je rozdělen na kvartily).

\section{A. Období rostoucích přírůstku HPH}

Jak již bylo uvedeno jako růstová období HPH byla nalezena období (2003 -2007) a (2009 2011). Tabulka 2 zobrazuje zdroje růstu v jednotlivých státech EU v obou sledovaných růstových obdobích. Již při prvním pohledu je zřejmé, že zdroje růstu jednotlivých států EU nejsou plně identické a že obě sledovaná období vykazují odlišný vývoj.

V růstovém období 2003 - 2007 byl zaznamenán převažující význam extenzivního růstu a to ve většině států EU. Výjimkou jsou dva státy a to Mad'arsko a Portugalsko, u kterých význam intenzivního růstu se pohybuje mezi $50 \mathrm{a} 75 \%$. 
Tabulka 2: Faktory růstu TFP v jednotlivých státech EU ${ }^{1}$ v letech 2003-2007 (rostoucí př́růstky $\mathrm{HPH})$

\begin{tabular}{|l|l|l|l|l|l|}
\hline & $<0 \%$ & $0 \%-25 \%$ & $25 \%-50 \%$ & $50 \%-75 \%$ & $>75 \%$ \\
\hline Extenzivní & & & EL,LU, HU,PT & $\begin{array}{l}\text { CZ,DK,GE,EE, } \\
\text { IE,MT, NL,AT, } \\
\text { PL,RO,SI,SK, } \\
\text { FI,SE,UK }\end{array}$ & $\begin{array}{l}\text { BE,BG,ES, } \\
\text { FR,IT, } \\
\text { CY,LV,LT }\end{array}$ \\
\hline Intenzitní & $\begin{array}{llll}\text { BE,BG,CY, } \\
\text { LV,LT, PL }\end{array}$ & $\begin{array}{l}\text { DK,IE,EL, } \\
\text { ES,FR,IT, } \\
\text { MT, RO,FI, } \\
\text { SE,UK }\end{array}$ & $\begin{array}{l}\text { CZ,GE,EE, } \\
\text { LU,NL, AT,SI, } \\
\text { SK }\end{array}$ & HU, PT & \\
\hline
\end{tabular}

Zdroj: vlastní zpracování, Eurostat

V pokrizovém období (2009 - 2011), kdy hrubá přidaná hodnota v jednotlivých ekonomikách států EU začíná pozvolně růst, vliv extenzivního faktoru není tak významný (tabulka 3). $\mathrm{V}$ tomto období v některých státech je extenzivní růst, tj. zvyšování počtu nových pracovních míst a výrobních kapacit potlačen ve prospěch intenzivního faktoru růstu. Tento jev můžeme například vidět u Irska, Dánska, Velké Británie, Španělska, Mad’arska a dalších. Větší vliv intenzivního růstu je zřetelný především u „starých“ států EU, a naopak menší vliv lze zaznamenat $u$ nově přistoupivších státi̊, u kterých je zjevná i nižší vybavenost práce kapitálem a větší vliv průmyslu na celkovou hodnotu HPH.

Tabulka 3: Faktory růstu TFP v jednotlivých státech EU ${ }^{1}$ v letech 2009-2011(opětovné pozvolné prírůstky HPH za průměr EU-27 zemí)

\begin{tabular}{|l|l|l|l|l|l|}
\hline & $<0 \%$ & $0 \%-25 \%$ & $25 \%-50 \%$ & $50 \%-75 \%$ & $>75 \%$ \\
\hline Extenzivní & $\begin{array}{l}\text { BG,DK,IE, } \\
\text { EL,ES,CY, } \\
\text { HU,PT,SI }\end{array}$ & $\begin{array}{l}\text { EE,LV,MT, } \\
\text { RO }\end{array}$ & $\begin{array}{l}\text { CZ,LT,NL,FI } \\
\text { UK }\end{array}$ & $\begin{array}{l}\text { BE,GE,FR,IT,LU, } \\
\text { AT,PL,SK,SE }\end{array}$ & \\
\hline Intenzitní & IT & $\begin{array}{l}\text { GE,EE,LV, } \\
\text { LU,MT }\end{array}$ & $\begin{array}{l}\text { BE,CZ,EL, } \\
\text { FR,LT,AT, } \\
\text { PL,RO, SK,FI, } \\
\text { SE }\end{array}$ & $\begin{array}{l}\text { BG,IE,ES,CY, } \\
\text { HU,NL,PT,SI,UK }\end{array}$ & DK \\
& & & & & \\
& & & SE & \\
\hline
\end{tabular}

Zdroj: vlastní zpracování, Eurostat

\section{B. Období stabilních př́růstků HPH}

V období mírného až stabilního růstu ekonomik EU v letech 1996 - 2000 má dominantní vliv u většiny států EU extenzivní růst spojený se zvyšováním produkčních schopností ekonomik (tabulka 4). Výjimky z pohledu extenzivního růstu najdeme i zde a jsou to: Česká republika, Slovenská republika a Litva, u kterých vliv extenzivního růstu nedosahuje více než $25 \%$ a v těchto státech je zřetelný větší vliv intenzivního růstu. Společným jmenovatelem pro uvedenou reakci u těchto 3 států je proces transformace na tržní ekonomiku.

\footnotetext{
${ }^{1}$ Belgie BE, Bulharsko BG, Česká republika CZ, Dánsko DK, Estonsko EE, Finsko FI, Francie FR, Irsko IE, Itálie IT, Kypr CY, Litva LT, Lotyšsko LV, Lucembursko LU, Mad’arsko HU, Malta MT, Německo GE, Nizozemsko NL, Polsko PL, Portugalsko PT, Rakousko AT, Rumunsko RO, Řecko EL, Slovensko SK, Slovinsko SI, Spojené království UK, Španělsko ES, Švédsko SE.
} 
Tabulka 4: Faktory růstu TFP v jednotlivých státech EU¹ v letech 1996-2000 (stabilní až mírně se zvyšující prírůstky HPH za průměr EU-27 zemí)

\begin{tabular}{|c|c|c|c|c|c|}
\hline & $<0 \%$ & $0 \%-25 \%$ & $25 \%-50 \%$ & $50 \%-75 \%$ & $>75 \%$ \\
\hline Extenzivní & $\mathrm{CZ}$ & LT, SK & $\begin{array}{l}\text { BG,EE,CY,LV, } \\
\text { AT }\end{array}$ & $\begin{array}{l}\text { BE, DK, GE, } \\
\text { FR, LU, HU, } \\
\text { NL,PL, PT, SI, } \\
\text { FI,SE,UK }\end{array}$ & IE,ES, IT \\
\hline Intenzitní & BG, IE, ES & $\begin{array}{l}\text { IT, LV,LU, } \\
\text { HU, PT }\end{array}$ & $\begin{array}{l}\text { BE, DK, DE, EE, } \\
\text { FR, LT, } \\
\text { NL,PL,SI,SK, FI, } \\
\text { SE, UK }\end{array}$ & $\mathrm{CZ}, \mathrm{CY}, \mathrm{AT}$ & \\
\hline
\end{tabular}

Zdroj: vlastní zpracování, Eurostat

\section{Období klesajících přírůstků HPH}

Období klesajících přírůstků hrubé přidané hodnoty (2000-2003 a 2007-2009) se zjevně liší. Je to dáno také tím, že intenzita a příčiny poklesu př́růstku HPH se v těchto období lišila. V období 2007-2009 jako v jediném je vykázán především vlivem roku 2009 průměrný pokles hrubé přidané hodnoty vEU, tím i faktory extenzivního růstu u většiny států jsou v záporných hodnotách a pouze u takových států jako je Bulharsko, Rumunsko, Kypr a Polsko představuje tento faktor $0-25 \%$ vliv. Intenzivní faktor v tomto období převažuje, tj. jeho podíl je od $50 \%$ do $75 \%$ u států jako je Itálie, Španělsko, Řecko. Tedy reakce zdrojů ekonomického růstu $\mathrm{v}$ jednotlivých státech EU byla u většiny států výraznější ve srovnání s obdobím 2000-2003. Došlo k významnému posunu k intenzivním zdrojům růstu (tabulka 5) a je zřejmý snižující se vliv extenzivní růstu tj. tahounem ekonomického růstu byl intenzivní faktor.

Tabulka 5: Faktory růstu TFP v jednotlivých státech EU1 v letech klesajících př́růstků HPH za průměr EU-27 zemí

\begin{tabular}{|c|c|c|c|c|c|}
\hline \multicolumn{6}{|c|}{ V letech 2000-2003 } \\
\hline & $<0 \%$ & $0 \%-25 \%$ & $25 \%-50 \%$ & $50 \%-75 \%$ & $>75 \%$ \\
\hline Extenzivní & $\begin{array}{l}\text { BE, DK, } \\
\text { GE,MT,NL,P } \\
\text { L, PT }\end{array}$ & FR,HU,AT,FISE & $\begin{array}{l}\mathrm{CZ}, \mathrm{IT}, \mathrm{SI}, \mathrm{SK}, \\
\mathrm{UK}\end{array}$ & $\begin{array}{l}\text { BG,IE,ES,CYL } \\
\text { V,LU, RO }\end{array}$ & EE, EL, LT \\
\hline Intenzitní & $\mathrm{BG}, \mathrm{CY}$ & $\begin{array}{l}\text { EE,GR,ES, } \\
\text { FR,IT,LT,LUM } \\
\text { T,FI }\end{array}$ & $\begin{array}{l}\text { IE,LV,AT, } \\
\text { RO,SK,SE }\end{array}$ & $\begin{array}{l}\text { BE,CZ,DK, } \\
\text { GE,HU,NL, } \\
\text { PO,PT,SI,UK }\end{array}$ & \\
\hline \multicolumn{6}{|c|}{ V letech 2007-2009 } \\
\hline Extenzivní & $\begin{array}{l}\text { BE,CZ,DK, } \\
\text { GE,EE,IE,ELES } \\
\text {,FR,IT,LV } \\
\text { LT,LU,HU, } \\
\text { MT,NL,AT, } \\
\text { PT,SK,FI, SE, } \\
\text { UK }\end{array}$ & $\begin{array}{l}\text { BG,CY,PL, } \\
\text { RO,SI }\end{array}$ & & & \\
\hline Intenzitní & $\begin{array}{l}\text { BE,GE,FR, } \\
\text { LU, NL, AT, } \\
\text { PT, FI, SE }\end{array}$ & $\begin{array}{l}\text { BG,CY,PL, } \\
\text { SI }\end{array}$ & $\begin{array}{l}\text { CZ,EE,IE,LV } \\
\text { LT,HU,MT,RO, } \\
\text { UK }\end{array}$ & $\begin{array}{l}\text { DK, EL, ES, IT, } \\
\text { SK }\end{array}$ & \\
\hline
\end{tabular}

Zdroj: vlastní zpracování, Eurostat

U nově přistupujících států EU je v období klesajících přírůstků HPH zřetelný větší vliv intenzivního faktoru než extenzivního. Jako jeden $\mathrm{z}$ důvodů může být výrazná průmyslová orientace těchto států, kdy podíl zpracovatelského průmyslu na celkové přidané hodnotě je vyjma Litvy vysoko nad průměrem EU. Průměrná hodnota tohoto podílu v EU byla v posledních 3 letech na úrovni $17 \%$. U nově přistupujících států se tato hodnota pohybuje v rozmezí 18,5 - 39,6 \%. Dalším faktorem je i nižší ekonomická úroveň nově přistupujících 
států (hodnota hrubého domácího produktu na obyvatele v paritě kupní síly nepřesahuje $85 \%$ průměru EU).

\section{Závěr}

Provedená analýza odpovídá na otázku, jak se vyvíjely ukazatele produktivity v posledních 16 let $\mathrm{v}$ průměru za EU i za jednotlivé státy, zejména objasňuje podíl extenzivního a intenzivního růstu v kontextu s cyklickým vývojem EU. Byla identifikována zjevná vazba na hospodářský cyklus, kdy především v obdobích klesajících př́írůstků hrubé přidané hodnoty, nabýval na významu intenzivní faktor růstu a naopak v obdobích zvyšujících se přírůstků HPH měl dominantní roli extenzivní růst.

V obdobích rostoucích prrírůstků HPH EU zejména v letech 2003-2007, kdy růst byl intenzivnější, se vyznačuje významným navyšováním technického vybavení práce, což vyvolává sice pokles produktivity kapitálu, ale produktivita výrobních faktorů TFP stále roste. $\mathrm{Z}$ detailnější analýzy byl zaznamenán převažující význam extenzivního faktoru růstu. Zatímco v druhém období označeném za „rostoucí“ tj. 2009-2011 zejména vlivem nejistého budoucího ekonomického vývoje byl ekonomický růst více tažen intenzivním faktorem.

V období stabilních přírůstků HPH EU (1996-2000) můžeme zaznamenat vysoké průměrné roční př́růstky produktivity práce, dominantní vliv má u většiny států EU extenzivní růst spojený se zvyšováním produkčních schopností ekonomik.

Období klesajících přírůstků hrubé přidané hodnoty EU (2000-2003 a 2007-2009) se značně liší. Je to dáno také tím, že intenzita a prríčiny poklesu přirůstku HPH se v obou intervalech lišily. Především v období 2007 - 2009 byla reakce zdrojů ekonomického růstu v jednotlivých státech EU výraznější ve prospěch intenzivního růstu ve srovnání s obdobím 2000 - 2003. Jedním z důvodů může být prííčina ekonomického poklesu, kdy v letech 2000 - 2003 byla recese způsobena především prudkým pádem cen informačních technologií (Sirůček et al. 2007). Naopak ekonomický pokles 2007 - 2009 byl způsoben finanční krizí v USA, která se následně přenesla do Evropské unie (Leschke, Jepsen 2012).

Z pohledu jednotlivých států EU jsou zřetelné rozdíly. Hlavní rozdíl můžeme nalézt mezi státy původní EU 15 a nově přistoupivšími členskými státy, kdy lze předpokládat, že tyto státy budou mít odlišný vývoj a konvergenci produktivity (Färe et al. 2006). U „nových“ států EU byl zjištěn větší vliv extenzivního faktoru růstu prakticky ve všech sledovaných intervalech, který je spojený se zvětšováním produkčních schopností. Celkově lze i v rámci EU najít společné rysy, které lze připsat zvyšujícímu se globálnímu propojení národních ekonomik.

\section{Literatura}

[1] AHLIN, C., J. LIN and M. MAIO, 2011. Where does microfinance flourish? Microfinance institution performance in macroeconomic context. Journal of Development Economics, 95(2), 105-120. ISSN 0304-3878.

[2] BANDA, S. H. and L. VERDUGO, 2011. Multifactor productivity and its determinants: an empirical analysis for Mexican manufacturing. Journal of Productivity Analysis, 36(3), 293-308. ISSN 0895-562X.

[3] BARRO, J. R. and X. SALA-I-MARTIN, 2004. Economic growth. London: The MIT Press, s. 24. ISBN 978-0-262-02553-9. 
[4] BAUMOL, W., 1967. Macroeconomics of Unbalanced Growth: The Anatomy of Urban Crisis. The American Economic Review, 57(3), 415-426. ISSN 0002-8282.

[5] COELLI, TJ. et al., 2005. An Introduction to Efficiency and Productivity Analalysis. Springer. ISBN 978-0387-24266-8.

[6] CYHELSKÝ, L., 1981. Úvod do teorie statistiky. Praha: SNTL/ALFA, s. 80.

[7] FÄRE, R., S. GROSSKOPF and D. MARGARITIS, 2006. Productivity Growth and Convergence in the European Union. Journal of Productivity Analysis, 25(1-2), 111141. ISSN 0895-562X.

[8] HAJEK M. and J. MIHOLA, 2009. Analysis of total factor productivity contribution to economic growth of the Czech Republik. Politická Ekonomie, 57(6), 740-753. ISSN 0032-3233

[9] IRMEN, A., 2005. Extensive and intensive growth in a neoclassical framework. Journal of Economic Dynamics and Control, 29(8), 1427-1448. ISSN 0165-1889.

[10] JÍLEK, J. a kol., 2005. Nástin sociálněhospodářské statistiky. Praha: VŠE, s. 219. ISBN 80-245-0840-0

[11] KYDLAND, F. E. and E. C. PRESCOTT, 1982. Time to build and aggregate fluctuations. Econometrica, 50(6), 1345-1370. ISSN 0012-9682.

[12] LESCHKE, J. and M. JEPSEN, 2012. Introduction: Crisis, policy responses and widening inequalities in the EU. International Labour Review, 151(4), 289-312. ISSN 1564-913X

[13] O'MAHONY, M. et al., 2009. Productivity growth in the US and the EU?: A sectoral analysis. National Institute of Economic and Social Research London [on-line]. [vid. 15.3.2009]. Dostupné z: http://www.niesr.ac.uk/

[14] PRAAG, M. and P. VERSLOOT, 2008. The Economic Benefits and Costs of Entrepreneurship: A Review of the Research. Foundations and Trends in Entrepreneurship, 4(2). ISSN 15513114.

[15] SIRU゚ČEK, P. et al., 2007. Hospodářské dějiny a ekonomické teorie. (vývoj-současnostvýhledy). 1. vydání. Slaný: Melandrium, s. 203. ISBN 978-80-86175-03-4.

[16] SOUKUP, J. et. al., 2007. Makroekonomie: Moderní přistup. 2. aktualizované vydání. Praha: Management Press, s. 518, ISBN 978-80-7261-174-4.

[17] SOLOW, R. A., 1956. Contribution to the Theory of Economic Growth. The Quarterly Journal of Economics, 70(1), 65-94. ISSN 0033-5533.

[18] YASSER, A. and F. JOUTZ, 2005. Relating the knowledge production function to total factor productivity: an endogeneous growth puzzle. Washington, DC [US]: International Monetary Fund, IMF Working Paper No. 05/74. 